\title{
Rusland og Vesten efter krigen i Georgien Mette Skak
}

\section{Det storpolitiske billede er ændret - fra en ned- ladende og passiv Ruslandspolitik til en mistroisk agtpågivenhed}

De overtroiske russere har det ikke godt med august måned. Det er den måned, hvor sommerheden topper, og når asfalten koger i Moskva forfalder magthaverne til dumheder.

Vi kan gå tilbage til Molotov-Ribbentrop-traktaten af 24. august 1939, hvis hemmelige tillæg gik hårdt ud over balterne, polakkerne, finnerne osv., og som fik Stalin til at sænke paraderne så meget over for nazismen, at han blev taget på sengen ved det tyske overfald 22. juni 1941.

Så er der invasionen af Tjekkoslovakiet 21. august 1968, som godt og grundigt delegitimerede kommunismen. Senere igen august-kuppet i 1991, der betød enden på Sovjetunionen og dermed sådan set endte godt. Dernæst den anden tjetjenske krig, der begyndte 26. august 1999, og som efter grumme krigshandlinger, herunder rædselsfuld terror fra den tjetjenske krigsherre Shamil Ba- saevs side, er endt med en russisk sejr og en stabilisering af situationen i Tjetjenien, men det er en mafiøs fred med Kreml-vasallen Ramzan Kadyrov som republikkens leder. Året efter, 12. august 2000 sank atom-ubåden Kursk i Barents Havet, og 118 besætningsmedlemmer druknede, mens Putin slappede af i Sochi og indkasserede sin første krise, som han drog den lære af, at medierne ikke længere skulle have frit spil.

I år kom det så til krig mellem Rusland og Georgien på 'superbryllupsdatoen' 08.08.08 - en krig, som Rusland har vundet militært, og som den russiske offentlighed hylder som en sejr for det genfødte Rusland; en krig, der imidlertid kan vise sig skæbnesvanger for netop Ruslands genfødsel.

Storpolitisk taler vi om et sammenbrud af tilliden mellem Rusland og 
det meste af omverdenen, og medier og meningsdannere vælter sig $\mathrm{i}$ kold krig og andre historiske analogier. Således taler den neo-konservative Robert Kagan om det 19. århundredes tilbagevenden i international politik med tanke på stormagten Ruslands knægtelse af småstaten Georgien, mens den russiske NATOambassadør Dmitrij Rogozin kalder den georgiske præsident Mikhail Saakasjvili for vor tids Gavrilo Princip: "Hele atmosfæren minder mig om situationen i 1914 [...] hvor verden brød i brand på grund af en enkelt terrorists handlinger" (Reuters, 26. august 2008).

Sexismen og racismen i Rusland har fået frit løb med tilsvininger af den amerikanske udenrigsminister Condoleezza Rice, og selv Ruslands pæne præsident Dmitrij Medvedev har taget fløjshandskerne af.

Allerede dagen efter Dumaens behandling af sagen skred han 26. august til diplomatisk anerkendelse af de georgiske udbryderrepublikker Sydossetien og Abkhasien og brød hermed punkt 6 i den fredsplan, som han selv 12. august havde underskrevet efter forhandling med EU-formanden, Frankrigs præsident Nicolas Sarkozy. Punkt 6 lagde op til internationale forhandlinger om Sydossetiens og Abkhasiens folkeretlige status og sikkerhed.

Senere 26. august erklærede Medvedev sig beredt til en ny kold krig, og på årsdagen for 11. september 2001 drog han - ret beset absurde - paralleller mellem $08.08 .08 \mathrm{og}$ USA's 9/11.

\section{Den hårde magts metoder}

Ruslands tilbagevenden til den hårde magts metoder og retorik er overraskende, for ellers var Kreml ved at få øjnene op for, at den bløde magt - dvs. at nyde respekt, at være en rollemodel - tæller lige så meget i nutidens storpolitik som tanks og missiler (se min artikel Medvedevs Rusland? Udenrigs, nr. 1, 2008).

Paradokset er så meget desto større, når man betænker den bløde magt, som Rusland faktisk har opnået i 2008: først vandt Ruslands Dima Bilan Melodi Grand Prix i maj; dernæst nåede det russiske fodboldlandshold trænet af den friske hollandske træner Guus Hiddink at blive alle fodboldfans' kæledægge som et nyt Brasilien under EM i fodbold i sommer. Rusland vandt ikke Europamesterskabet, men det var tæt på, og sejrsrusen hjemme i Rusland antog former, der mindede om den Orange Revolution i Ukraine.

Måske var stemningen i Rusland en medvirkende faktor bag Kremls markante stilskift med straffeaktionen mod Georgien? I hvert fald er det lykkedes Kreml at få det russiske baglands begejstrede opbakning gennem en ganske vist fordrejet fremstilling af forløbet og perspektiverne i medierne. Der er dog vigtige undtagelser blandt russiske sikkerhedspolitiske eksperter. Dem vender 
jeg tilbage til. Ærindet her er at se på Georgien-Ruslandkrigen i fugleperspektiv og belyse, hvad der er gået galt i forholdet mellem Rusland og Vesten forud for krigen og komme med nogle bud på, hvad man kunne have gjort, og hvad man fremover kan gøre (samt hvad man bør undgå at gøre) for at bringe forholdet på ret $\mathrm{k} ø l$.

Jeg vil også drøfte, hvordan situationen tegner sig for Rusland for at belyse min tese om, at hele miseren kan ende i meget store problemer for Rusland. For den kulde, der nu omgiver Rusland, er for en stor del selvforskyldt og berettiget.

\section{Legitimitet bliver trumf fremover}

Alligevel er budskabet i min analyse, at Vesten må gribe i egen barm og tænke sin Ruslandspolitik og bredere østpolitik, ja hele sin sikkerhedspolitik grundigt igennem før NATOtopmødet i december. Mødet er berammet til at skulle behandle den ømtålelige sag om en MAP, en Membership Action Plan, dvs. en optagelsesprocedure for Georgien og Ukraine; noget, som mange anser for den egentlige casus belli for Kreml snarere end det georgiske overfald på Sydossetien 7. august 2008.

Analysen bygger blandt andet på informationer og vurderinger fra rapporten Russia vs Georgia: The Fallout, Europe Report No. 195 - 22 August 2008 udgivet af International Crisis Group, herefter ICG.
Som tænketank er ICG yderst velanskrevet og redelig, derfor vil jeg indlede med at citere, hvordan dette uafhængige kriseanalytikerforum så på situationen endnu før Rusland var skredet til anerkendelse af de to georgiske udbryderrepublikker: "Rusland-Georgien-konflikten har ændret vor tids geopolitiske verden med store konsekvenser for freden og sikkerheden i Europa og videre ud i verden" (ICG).

Med andre ord ikke nogen triviel sag, derfor er der ekstra grund til omtanke. Man gør klogt i at se den kaukasiske konflikt i sammenhæng med den magtspredning, der foregår i international politik i disse årtier med opkomsten af ikke bare Rusland, men hele gruppen af BRIKlande (Brasilien, Rusland, Indien og Kina), ja resten af verden, som påpeget af den amerikansk-indiske politolog Fareed Zakaria i hans bog med den rammende titel The PostAmerican World fra 2008.

Det er vigtigt ikke at tolke den storpolitiske verden, som vi hermed bevæger os ind i, som en anti-amerikansk verden, understreger Zakaria. Tværtimod er det en rummelig verden med plads til alle, også EU og USA, for det vil ikke bare være staternes verden, men lige så meget befolkningernes verden, derfor bliver den afgørende ressource i international politik legitimitet, vurderer han (ibid. s. 39).

BRIK-landene som stormagter er modsat tidligere tiders opkomlinge 


\section{METTE SKAK}

ikke for alvor interesseret $i$ at vende op og ned på verdensordenen, for det er de eksisterende globale vilkår, især globaliseringen, som har skubbet dem frem på arenaen. De har simpelthen en vital interesse $i$ at bevare systemet og være medspillere.

Det er noget, som vi i Vesten må udnytte til at gøre dem mere medansvarlige - vi skal tænke i modeller for deres aktive og konstruktive bidrag til at løse de store spørgsmål i international politik. I den forbindelse skal vi ikke skrotte vore egne værdier, tværtimod skal vi sørge for at de løbende får serviceeftersyn ud fra hensynet legitimitet. På det punkt har navnlig USA fået ferniseret sig op i et hjørne pga. de mange problematiske træk i Bush-administrationens sikkerhedspolitik.

\section{USA's arrogance}

USA har ligesom Rusland optrådt arrogant og tilsidesat FN i forbindelse med krigen mod den ganske vist ikke folkevalgte Saddam Hussein, som udløste et regimeskift i Irak. Hertil kommer USA's pres på NATO for at få alliancen til over hals og hoved at forpligte sig til at optage Georgien og Ukraine, en sag alle ved er en rød klud for Rusland, samtidig med, at USA presser på for at få mange flere europæiske tropper til ISAF-styrken i Afghanistan. Det hænger simpelthen ikke sammen.

Hvad NATO-udvidelsen angår, er det naturligvis ikke Rusland, der skal bestemme over andre suveræne staters sikkerhedspolitiske valg. Men det er ulyksaligt, at det er lige præcis det ustabile Georgien i det fjerne Kaukasus, en stat ledet af styrvolten Saakasjvili, samt den geopolitiske sværvægter Ukraine, som tilbage i vikingetiden var forspillet til Rusland som stat, og som i sikkerhedspolitiske præferencer nærmest knækker over på midten, der af USA er blevet udset til at være trofæerne i NATOs kommende udvidelse (Washington Post, 2. april 2008).

Hvis man gerne ville opnå resultater, skulle man i første omgang have begrænset sig til det stilfærdige Moldova, hvis ledelse forholdsvis pragmatisk har håndteret de mange holmgange med Kreml og udbryderrepublikken Transnistrien.

Som modydelse til Rusland for et evt. moldovisk medlemskab af NATO og for de problemer, som Kosovos uafhængighed måtte have skabt, kunne man overveje at gøre det særtilfælde, som Transnistrien sådan set er, til en uafhængig stat.

Således kunne både Rusland og Vesten lukke sagen om Kosovo, for det er under alle omstændigheder en gylden regel, at det internationale samfund bør være yderst forsigtigt med at skabe nye stater. Rusland ville redde ansigt på en måde, så Kreml undgik at åbne den Pandoras æske af etniske og religiøse konfiktpotentialer og løsrivelsesønsker, som præger Kaukasus, og som kan ende med at vække Tjetjenien-krigene til 
live påny. For Moldova kunne det gavne stabiliteten og den økonomiske normalisering at blive fri for det uregerlige og mafiøse Transnistrien.

Vesten ville gennem de forpligtelser, der også påhviler en suveræn europæisk stat, få nye redskaber til at bekæmpe kriminaliteten, herunder kvindehandelen i Transnistrien gennem dets optagelse i Europarådet, som 1. februar i år lod en banebrydende Convention on Action against Trafficking in Human Beings træde i kraft. NATO kunne i det hele taget have taget ved lære af den lange og omhyggelige sikkerhedspolitiske forberedelse af EU's udvidelse mod øst, som byggede på skabelsen af en europæisk stabilitetspagt, hvor Rusland var med ved forhandlingerne om mindretalsproblemerne i Baltikum.

Hertil kommer de nordiske landes og Tysklands aktive tillids- og sikkerhedsskabende diplomati over for Rusland gennem Østersørådet. For som ofte påpeget af Det Udenrigspolitiske Selskabs direktør Klaus Carsten Pedersen er det noget vrøvl, når russerne hævder, at jorden vil gå under den dag, NATO grænser op til Rusland. Det har Rusland jo gjort siden 1949 i Norge, og nordmænd er bestemt ikke højt placeret på listen over de nationer, som russerne føler sig truet af.

Sidst, men ikke mindst er det spørgsmålet, om ikke et tilbud om en MAP bør figurere som et perspektiv for Rusland selv - her kunne
Ruslands selvforståelse som først og fremmest en autonom aktør bruges til at afskærme NATO mod handlingslammelse som følge af russiske vetoer.

At der er behov for stadig at tænke i Ruslands medinddragelse i NATO uden at gå på kompromis med hensynet til de nuværende NATO-medlemmers sikkerhed anerkendes også af ICG (s. 12, note 66).

\section{Ruslands Monroe-doktrin}

En og anden vil nok anse mine NATO-udvidelsesscenarier for luftkasteller, for med den arrogance, som Rusland nu lægger for dagen, er tiden forpasset for et konstruktivt russisk medspil. Det er muligt, men det er under alle omstændigheder ikke godt, at NATO er slået ind på så hovedkulds en udvidelsespolitik, som tilfældet er, for legitime og gennemtænkte politikker er vigtige for NATO også indadtil - af hensyn til opbakningen fra alliancens egne befolkninger.

Man kan indvende, at Rusland når det kommer til stykket er ligeglad med legitimitet og kun agerer magtpolitisk. Igen en såre relevant betragtning, men alligevel en forenkling, for de russiske udenrigspolitiske meningsdannere tænker og i hvert fald argumenterer samtidig ud fra princippet om gensidighed.

Heri læner de sig op ad den ene af den internationale politiks to folkeretlige hovedhjørnesten - princip- 


\section{METTE SKAK}

pet om at udveksle omtrent lige store størrelser, hvad enten det er begunstigelser, sanktioner, miliær gengældelse eller hjælp; det andet grundprincip er princippet om ikkeindblanding $\mathrm{i}$ indre forhold (Robert Jackson, Quasistates, 1993, s. 6).

Sagen er, at den russiske politiske elite lige siden Den Russiske Føderation kom til verden på ruinerne af Sovjetunionen med indiskutabel inspiration fra USA og dets eksklusive Latinamerika-politik har henholdt sig til en 'Monroe-doktrin', hvorefter hele det post-sovjetiske rum anses for Ruslands vitale interessesfære. Bagmanden for denne opsigtsvækkende melding - som verden siden lykkeligt har glemt - var en af den daværende præsident Boris Jeltsins rådgivere, Andranik Migranjan, som i 1994 skrev:

"I en række artikler i Rossijskaja Gazeta formulerede jeg [...] den centrale ide, der dernæst blev afgørende for forståelsen [...] blandt alle ledende politikere i Rusland lige fra præsidenten til udenrigsminister Kosyrev.

Den går i al korthed ud på, at hele det tidligere Sovjetunionens geopolitiske rum er Ruslands vitale interessesfære. For at ikke nogen skulle være i tvivl om, hvad der tænkes på med vitale interesser, trak jeg en parallel til Monroe-doktrinen. I en vis forstand gjorde jeg et forsøg på at formulere en russisk Monroe-doktrin, der var anvendelig på den nuværende situation, der er opstået ef- ter Sovjetunionens opløsning.” (Rusland og det 'nære udland', SNUPapers, 1994, s. 9).

Ifølge Migranjan selv blev ideen bredt accepteret allerede i 1992, og den kaster dermed lys over Ruslands kontroversielle militære interventioner i konflikterne i Transnistrien, Sydossetien og Abkhasien 1992-93. Jeltsin tog ifølge ham denne Monroe-doktrin til sig i marts 1992, og da Jeltsin i august 1993 sagde, at Tadsjikistans sydgrænse faktisk også var Ruslands sydgræense, fandt vittige hoveder i Vesten på termen Monrovski-doktrin.

Senere, i begyndelsen af 1994 på den årlige konference for Ruslands SNG-ambassadører, udtalte Kosyrev, at "SNG-landene og Baltikum er den region, hvor Ruslands primære og livsvigtige interesser er koncentreret. Derfra udgår samtidig de fundamentale trusler mod vore interesser".

Det fik den kazakstanske sikkerhedsanalytiker Umirserik Kasenov til at bruge overskriften " Kosyrevdoktrinen - en russisk variant af Monroe-doktrinen "? (Nezavisimaja Gazeta, 12. marts 1994). Kasenov holdt sig ikke tilbage for samtidig at parallellisere til Bresjnev-doktrinen om 'begrænset suverænitet' og bemærkede, at den nye doktrin ligesom Bresjnev-doktrinen lægger op til væbnede interventioner om nødvendigt. Forskellen ligger i, at Bresjnev-doktrinen gjaldt Sovjetunionens såkaldte internationale forpligtelser, 
nemlig forsvaret af socialismen, mens nye dotrin gælder forsvaret af Ruslands vitale nationale interesser (ibid.).

\section{Russisk nationalisme}

Denne iagttagelse er meget præcis. Siden Sovjetunionens sammenbrud har det russiske udenrigspolitiske establishment ivrigt kastet den marxistiske internationalisme overbord til fordel for russisk nationalisme og en angiveligt normal statsræson. Problemet er den stormagtsidentitet og imperialistiske udenrigspolitiske kultur, som samme establishment holder fast i (se min bog From Empire to Anarchy, 1996, ss. 137-191).

De kommer til udtryk i tesen om, at stormagter har særlige privilegier og en særegen autonomi - sidstnævnte er det, som man iflg. mine højtplacerede russiske samtalepartnere skal lægge i den tidligere præsident Vladimir Putins slogan om 'det suveræne demokrati' - og endvidere i den russiske udenrigspolitiske praksis, hvorefter magt ofte er lig med ret ( $\mathrm{fx}$ i gaskrigene mod GUAM-landene Georgien, Ukraine og Moldova samt Hviderusland).

Mulighederne for magtmisbrug er til at tage at føle på, idet Kosyrev ved samme lejlighed i 1994 gjorde opmærksom på, at "forsvaret af folk med russisk statsborgerskab (rossija$n e$ ) i det nære udland (dvs. det postsovjetiske rum/MS) er det strategiske hovedspørgsmål i Ruslands udenrigspolitik" (ibid.; Nezavisimaja Gazeta 19. januar, 1994).

Ind imellem Migranjans kampagne for sin Monroe-doktrin i 1992 og Kosyrevs åbenlyse tilslutning til den i 1994 forsøgte det officielle Rusland med Jeltsin i spidsen i løbet af 1993 forgæves at overtale FN til at give Rusland carte blanche til generelt at påtage sig fredsbevarelsen i det postsovjetiske rum under henvisning til, at hverken FN eller OSCE havde afsat ressourcer til eller vist interesse for at gøre sig gældende i regionens mange brændpunkter.

Men førnævnte Kasenov påpegede allerede i 1994, at Ruslands fredsbevarende styrker let bliver besættelsestropper og en trussel mod de nye post-sovjetiske staters suverænitet på det punkt fandt han Ruslands optræden i de abkhasisk-georgiske og moldovisk-transnitriske konflikter bekymrende (ibid., 12. marts, 1994).

Kasenov spurgte derfor vantro, om det virkelig kan passe, at Rusland læner sig op ad den famøse amerikanske Monroe-doktrin fra 1823 inklusive den militære udmøntning, som den senere amerikanske præsident Theodore Roosevelt blev berygtet for med sin anmodning til Kongressen af 6 . december 1904 om at godkende, at USA påtog sig rollen som gendarm over for de ustabile og 'magtesløse' latinamerikanske stater? (ibid.).

I november 1993 gjorde den daværende chef for Ruslands CIA, Sluzjba Vnjesjnjej Razvedki (SVR), den 


\section{METTE SKAK}

senere udenrigsminister Jevgenij Primakov det klart, at en udvidelse af NATO ville true Ruslands interesser og gav hermed bolden op til det fastlåste russiske syn på sagen (Izvestija, 26. nov. 1993).

Ganske vist var tonen her afdæmpet, idet SVR vedgik, at Rusland ikke længere kunne diktere $\varnothing_{\text {st- og }}$ Centraleuropas sikkerhedspolitik, men man krævede hensyntagen til Ruslands interesser, dvs. et holistisk system for kollektiv sikkerhed i Europa, et mål Rusland skulle forfølge via en såkaldt multivektor-politik, et slogan, Putin har taget til sig.

Sidst i 1995 var Primakov mere kontant og kaldte NATO-udvidelsen en sikkerhedstrussel for Rusland. Navnlig lovede han, at SVR vil blokere udvidelsen og samtidig opbygge et godt forhold til de tidligere koldkrigsmodstandere, omend det for ham - allerede da, dvs. før Bush, Cheney og Rumsfeld! - gjaldt om at modvirke USA's 'globale hegemoni' (http://www.globalsecurity.org/ intell/world/russia/svr-ops.htm).

Kort sagt blev Ruslands udenrigsog sikkerhedspolitik nærmest fra starten afsporet i retning af antiamerikanisme og nyimperialisme over for det post-sovjetiske nærområde med disse tilkendegivelser, der endvidere relativiserede Polens og andre fhv. Warszawa-pagtlandes suverænitet.

Den her beskrevne voldsomt asymmetriske russiske tilgang til Ruslands egen og dets nabolandes suveræni- tet kolliderer frontalt med princippet om ikke-indblanding samt med den gældende europæiske forståelse af den sikkerhedspolitiske orden i Europa, hvorefter sikkerheden er udelelig, og hvor man ikke kan fortænke balterne, polakkerne og andre i ikke at have alverden af tiltro til russiske sikkerhedsgarantier.

\section{Amerikansk anakronisme}

Så vi europæere står med et akut problem - men det gør Rusland også, for Rusland vil gerne tages på ordet som et europæisk land, spørg bare Putin og Medvedev. Spørgsmålet er faktisk, om ikke problemet ligger hos det USA, der fortsat henholder sig til Monroe-doktrinen? I hvert fald har vi tilgode at høre den amerikanske præsident officielt frasige sig doktrinen på trods af, at den virker mere og mere anakronistisk i den globaliserede verden, vi lever i.

For det første giver Monroe-doktrinen og den nordamerikanske arrogante adfærd, der følger med den, voldsomme gnidninger og mistillid til USA fra latinamerikanernes side, hvilket simpelthen ikke kan være Washingtons strategiske interesse som liberal aktør i international politik.

For det andet har Sovjetunionen for længst med sin åbenlyse støtte til Fidel Castros Cuba udstillet Monroedoktrinen som ønsketænkning fremfor realitet, og Putins Rusland fortsætter i samme skure med støtte 
til såvel Cuba som Venezuela under den lige så anti-amerikanske Hugo Chavez.

Så mon ikke tiden er inde til, at Europa diskret og høfligt hjælper USA til at reparere på sit noget flossede ry i international politik ved at opfordre det Hvide Hus til officielt at frasige sig doktrinen? I hvert fald kan alle nu med Ruslands krig mod Georgien og de mere eller mindre skjulte dagsordener, der knytter sig hertil, se at Monroe-doktrinen - utilsigtet - er endt med at ride den euroasiatiske region som en mare på grund af den russiske forkærlighed for at tænke og handle ud fra filosofien om gensidighed - gensidighed stormagterne imellem forstås.

\section{Priviligerede interesser}

Jeg skal ikke foregøgle nogen, at et sådant amerikansk skridt vil være den mirakelkur, der straks får Rusland på andre tanker angående udvidelsen af NATO og som vil civilisere dets fremfærd i det nære udland. Men det vil give Vesten en anderledes holdbar platform at arbejde ud fra i forhandlingerne med Kreml et kærkomment håndtag i form af styrket legitimitet og troværdighed.

Spørgsmålet er blevet aktualiseret af, at Medvedev den 31. august, altså dagen før han påny skulle mødes med EU-formanden Sarkozy angående Georgien-krigen, valgte at præcisere dette års officielle russiske udenrigspolitiske doktrin med fem yderligere punkter, hvoraf punkt 5 er det afgørende. Det gentager den russiske Monroe-doktrin og bekræfter Ruslands vilje til at holde fast i gamle venner såsom Syrien.

Han sagde: "Ligesom andre lande i verden har Rusland regioner, hvor det har priviligerede interesser. Lande, som vi traditionelt har været knyttet til med venlige og høflige relationer; i disse regioner er der historisk set særlige relationer. Vi vil arbejde meget indgående med disse egne. Og udvikle venlige relationer med disse lande og med vore nærmeste naboer. Det vil jeg tage som udgangspunkt i udførelsen af vores udenrigspolitik" (Medvedev som gengivet af SNG-eksperten Vladimir Zjarihin i Izvestija, 17. sept., 2008; se også RIA Novosti 31. aug., 2008).

Punkt fem blev kommenteret af vestlige iagttagere som Arnaud de Borchgrave, der mener, at Medvedevs slebne ord rummer en besked til USA om at fjerne sin bagdel fra de fhv. Sovjet-republikker samt Sovjet-klienter og allierede. Han placerer Medvedevs Monroe-doktrin i sammenhæng med Kremls og ikke så få andres overbevisning om, at Bush-administrationens globale korstog for demokrati blot er et dække for imperialt overmod - hybris (The Washington Times, 4. sept. 2008; se også Paul Reynolds i BBC News 1. sept., Andrew E. Kramer i New York Times, 1. sept. 2008).

Russeren Zjarihin mener, at de Borchgrave rammer hovedet på 


\section{METTE SKAK}

sømmet med sin tese om, at Rusland blot giver igen over for de amerikanske neo-konservative. Helt parallelt anser politologen Marina Peunova de russiske imperiebyggere for russiske neo-konservative og dokumenterer deres egen brug af ordet (CEU Political Science Journal, Nr. 2, 2007). Zjarihin minder om, at Ruslands insisteren på multipolaritet ikke handler om alskens små- og mellemstore stater, men om veto-magterne i FN's Sikkerhedsråd, som han ligefrem kalder FN-politbureauet (Izvestija, 17. sept. 2008).

Faktisk kalder han også Ukraines præsident Viktor Jusjtjenkos reaktion for fint afstemt: "Lad mig sige det ligeud: vi er bekymrede over begrebet om regioner for den Russiske Føderations privilegerede interesser" (ibid.). Ligesom mange menige ukrainere frygter Jusjtjenko, at Ukraine er næste mål for væbnet russisk disciplinering.

I den forbindelse er det ikke til megen hjælp, når netop amerikanske toppolitikere som Rice ureflekteret lover at "modvirke ethvert russisk forsøg på at inddrage suveræne stater og frie folk i en arkaisk 'indflydelsessfære' " (Secretary Rice addresses U.S.-Russia Relations At The German Marshall Fund).

\section{Skyldsspørgsmålet}

Hidtil er spørgsmålet om ansvaret for udbruddet af den georgisk-russiske krig ladt ude af betragtning, selv om analysen ovenfor gør krigen til et led i Ruslands nyimperialisme. Skyldsspørgsmålet er imidlertid mere kompliceret end som så.

Som ICG fremstiller det, begyndte krigshandlingerne ved, at Georgien via en overordnet officer meddelte, at Tbilisi før midnat 7 . august 2008 havde besluttet at genroprette den forfatningsretlige orden i Sydossetien. Kl. 01:00 8. august anrettede georgiske styrker et massivt militært angreb på republik-hovedstaden Tskhinvali, hvorefter russiske tanks ved 01:30-tiden rykkede ind i Georgien gennem Roki-tunnelen.

"Åbenbart havde russerne forudset det georgiske angreb, omend de måske ikke ligefrem provokerede det", skriver ICG. Fra russisk side understreges det, at sagens kerne er dette overlagte angreb fra georgisk side, ergo at det russiske modangreb falder ind under artikel 51 i FN-pagten, der handler om retten til selvforsvar. Putin talte om et georgisk folkemord mod osseterne, idet russiske kilder oprindelig anslog, at op mod 2000 civile omkom.

Men selv om kampene var intense, var disse tabstal vildt overdrevne - russiske militære kilder dokumenterede 133 dræbte civile, mens $\mathrm{Hu}$ man Rights Watch taler om under 100 civile tab. Derfor erkender russiske analytikere nu, at det var en fejl at tale om folkemord, selv om de fortsat anser Saakasjvili for en krigsforbryder (Russia Profile, 16. september 2008). 
Det står forholdsvis klart, at Saakasjvili var den, der forløb sig ved at indlede et omfattende angreb på Sydossetien - eller som den svenske udenrigsminister Carl Bildt har sagt: "Når man har valget mellem intet at gøre og gøre noget dumt, er det bedre ikke at foretage sig noget" (Economist, 14. august, 2008).

Men Economist og mange andre, heriblandt fremtrædende kritiske russiske iagttagere anser det for en krig, som Rusland har planlagt og dermed har ansvaret for. Således har den velanskrevne Pavel Felgenhauer påvist en optrapning fra sydossetisk side, idet han 7. august 2008 på Eurasia Daily Monitor offentliggjorde en analyse med den profetiske titel "Ossetian separatists are provoking a major Russian intervention".

Her henledte han opmærksomheden på sydosseternes evakuering af kvinder og børn til Nordossetien efter en vejsidebombe mod georgisk politi 31. juli, samtidig med at den brutale sydossetiske leder Eduard Kokoity organiserede forstærkninger - 300 frivillige politisoldater og paramilitære fra Nordossetien. Men Felgenhauers materialer tyder samtidig på, at sydosseterne på det tidspunkt følte sig svigtet af Kreml.

Andre har peget på, at så knusende som det russiske svar var, vidner det om planlægning og mobilisering, og Felgenhauer udgav 14. august en ny analyse med titlen "The Russian-Georgian war was preplanned in Moscow". Heri skrev han, at den udløsende faktor var Georgiens tilnærmelse til NATO og det humanitære motiv angående Sydossetien blot et påskud.

\section{ICG's anbefalinger}

Såvel ICG som andre kredse i Vesten er imidlertid skeptiske ikke bare over for den officielle russiske version, men også over for den officielle georgiske og anbefaler en upartisk kulegravning af hændelsesforløbet. Navnlig i Tyskland nager tvivlen om Saakasjvilis version. Tyske militære OSCE-folk stationeret i Tbilisi afviser hans påstand om at russerne var begyndt at invadere gennem Roki-tunnelen før det georgiske angreb (http:/ /www.spiegel.de/ international/world/0,1518,druck$578273,00 . \mathrm{html}$ ).

Irakly Okruasjvili, der var forsvarsminister fra 2004 til 2006, hævder, at invasionen af Sydossetien var planlagt, men at Saakashvili begrænsede sig til erobringen af Tskhinvali i håbet om, at USA ad diplomatiske kanaler ville afskære Rusland fra at svare. Ifølge ham overså Saakasjvili den russiske militæropbygning i regionen, hvorfor man under alle omstændigheder efterlades med indtrykket af et lovlig velforberedt russisk svar.

Om ikke andet må man sige, at selv om georgiske høge som Okruasjvili og Saakashvili ifølge ICG har torpederet tillidsskabelse over for Abkhasien og Sydossetien og derfor 
ligger som de har redt, har Rusland fisket i rørte vande lige siden 1992. Det var Kreml, der fandt på at give russiske pas til folk i det to udbryderrepublikker, så de kunne blive frænder, som den russiske stat skal beskytte. På det punkt gør ICG det klart, at Rusland misbruger den nye FN-norm Responsibility to Protect. Den kan ikke simpelthen ikke bruges på den måde, som russerne forsøger.

ICG anbefaler NATO ikke at træffe beslutninger om en MAP til Georgien og Ukraine lige nu, hvor stemningen er oppisket som følge af lynkrigen. I stedet foreslås en tænkepause, hvorunder NATO ifølge ICG passende kan overveje andre måder at sikre Georgien og Ukraine på såsom en begrænset sikkerhedsgaranti til Georgien, hvor NATO-forpligtelsen ikke gælder de to udbryderrepublikker, kun det resterende Georgien. Det ville vise, at Rusland ikke har frit spil i Georgien uden at give Tbilisi rygdækning til nye uoverlagte angreb mod udbryderrepublikkerne.

Som nævnt kom ICG's rapport før den russiske anerkendelse af udbryderrepublikkerne: et skridt, som selv russiske analytikere vedgår var det afgørende faux pas (Russia Profile, 16. september, 2008). Alligevel holder flere bidrag skrevet efter dette skridt fast i opfordringen til NATO om ikke at handle overilet med udvidelsen, eksempelvis Morton Abramowitz, der hører til ICG's eksekutivkomite (Georgia on our
Mind, www.nationalinterest.org).

ICG mener, at Rusland må holdes fast på den 6-punktsplan, der blev indgået midt $\mathrm{i}$ august $2008 \mathrm{og}$, at der må sikres en upartisk international overvågning af hele Georgien. I tilfælde af russisk obstruktion kan man så overveje modforholdsregler mod Rusland mht. G8 og WTO og evt. vinter-OL i 2014, som jo er berammet til at skulle finde sted i Sochi ikke langt fra konfliktzonen, dvs. tæt på Abkhasien.

ICG anser konflikten for at handle om Ruslands vrede over NATOudvidelsen, Kosovo, missilforsvarsprojektet og dets doktrin om begrænset suverænitet parret med ny udenrigspolitisk selvtillid og aggressivitet - tendenser, som henføres til Putin som afgørende lederskikkelse. Altså en blanding af opsparede og til dels forståelige frustrationer og andre, mere irrationelle og konjunkturbestemte impulser i Kreml.

\section{Status for Rusland - og Vesten}

Summa summarum er det mest foruroligende ved hele sagen ikke så meget krigsførelsen, som var såre disproportional fra russisk side med overgreb og plyndringer mod civile i kølvandet, men snarere den efterfølgende russiske vilje til at skabe fuldbyrdede kendsgerninger begyndende med anerkendelsen af Sydossetien og Abkhasien 26. august.

Således er det ikke bare skinger retorik mellem Moskva og Washing- 
ton - det er kommet til følen på tænderne mellem NATO-fartøjer og russiske krigsskibe i Sortehavet. Den 17. september indgik Rusland venskabsaftaler med Sydossetien og Abkhasien - aftaler, der åbner for militært samarbejde, måske baser - og dagen efter brød forhandlingerne mellem OSCE og Rusland om overvågningen af Sydossetien sammen.

USA er chokeret over Ruslands signal om at ville sælge Iran det meget avancerede S-300 luftforsvarssystem, som i givet fald vil sætte de israelske og mange amerikanske missiler ud af spillet. Iflg. den private amerikanske efterretningstjeneste Stratfor er signalet til Washington: "Støt I bare Georgiens og Ukraines NATO-medlemsskab; så får I S-300 i Iran!" (http://www.telegraph.co.uk /news/worldnews/europe/russia).

Det russiske forsvarsbudget for 2009 er blevet justeret kraftigt op som reaktion på udviklingen i Kaukasus, hvortil kommer Medvedevs løfte om ensidigt at påbegynde grænsedragningen mellem Sibirien og Nordpolen af hensyn til Ruslands andel i de formodede rige energiressourcer i Arktis (RIA Novosti, 17. sept. 2008). Det udfordrer en aftale med blandt andet Danmark.

Man kan imidlertid argumentere for, at disse manøvrer allesammen er forsøg på at smede, mens jernet er varmt - at den underliggende realitet er, at konjunkturerne for Ruslands storhed er ved at vende. Georgien-krigen har vitterlig ændret det storpolitiske billede fra en lidt nedladende, men samtidig ret passiv og harmløs Ruslandspolitik til en anderledes mistroisk agtpågivenhed.

Selv om man ikke skal overdrive Ruslands sårbarhed, er det et faktum, at krigen har genskabt kapitalflugten fra landet - pr. 4. september 2008 opgjorde Financial Times den samlede sum siden juli til 21 mia. USD - rublen er svækket, og olieprisen er faldet fra over 147 USD pr. tønde den 11. juli 2008 til under 100 USD.

Ruslands radikalt nye anerkendelsespolitik chokerer ikke bare Vesten, men også venner som Serbien, Kina og andre lande i Eurasien, der ikke skal nyde noget af separatisme og ørkesløse konfrontationer med Vesten. Førnævnte Felgenhauer fremmaner et radikalt indskrænket handlerum for Rusland og spår en eskalering af konflikterne i hele Kaukasus-regionen inklusive partisankrige mod Rusland fra de to nye selvstædige stater. Han mener, at de to kan ende med at ødelægge Rusland, selv om det næppe vil anfægte Kreml-eliten i dens statsfinansierede boliger (Novaia Gazeta, 1. september 2008).

Selv om Europa er meget afhængig af gasimport fra Rusland, er efterspørgslen kulmineret og falder nu med 2 pct. årligt, hvilket sløver det russiske gasvåben, hvortil kommer, at olievåbnet nærmest er ikkeeksisterende (http://www.ecfr.eu/ content/entry/russia_threats_just_ 


\section{METTE SKAK}

gas/). Strukturelt er Rusland meget dårligt klædt på til at kaste sig selv ud i konfrontation med Vesten: der er nedarvede problemer som højst ineffektiv militarisme, korruption, ensidig eksportstruktur, underinvestering i uddannelse og fordummelse af den offentlige mening $\mathrm{fx}$ angående Ruslands forhold til omverdenen.

På kort sigt har ledelsen befolkningen med sig, men inflation og nedgang i velfærden kan give uro.

Men som jeg har argumenteret, betyder det ikke, at vi bare kan afvente situationen og køre NATObusiness as usual. Hele østpolitikken må tænkes igennem, så der sendes klare signaler om grænsen for vores engagement og sikkerhedsgarantier således, at selv eventuelle tvetydigheder er tilsigtede og udtryk for gennemtænkt politik.

For at højne EU's handlefrihed over for Rusland er det klogt - også miljømæssigt - at sænke forbruget af fossile brændstoffer, men så længe der er dunkle punkter om forløbet af Georgien-Rusland-krigen, skal vi ikke overreagere og isolere Rusland.

I særdeleshed duer det ikke i en magtspredningstid som vores at forlange af Rusland, at det afsværger sin nyimperialisme og doktrin om begrænset suverænitet, hvis ikke andre gør ligeså.

Mette Skak er lektor ved Institut for Statskundskab, Århus Universitet. 